\title{
Upcycling the Spent Mushroom Substrate of the Grey Oyster Mushroom Pleurotus pulmonarius as a Source of Lignocellulolytic Enzymes for Palm Oil Mill Effluent Hydrolysis
}

\author{
Nurul Anisa Mat Yunan ${ }^{1,2}$, Tan Yee Shin ${ }^{1,2 *}$, and Vikineswary Sabaratnam ${ }^{1,2}$ \\ 'Mushroom Research Centre, Universiti Malaya, 50603 Kuala Lumpur, Malaysia \\ ${ }^{2}$ Institute of Biological Sciences, Faculty of Science, Universiti Malaya, 50603 Kuala Lumpur, Malaysia
}

Mushroom cultivation along with the palm oil industry in Malaysia have contributed to large volumes of accumulated lignocellulosic residues that cause serious environmental pollution when these agroresidues are burned. In this study, we illustrated the utilization of lignocellulolytic enzymes from the spent mushroom substrate of Pleurotus pulmonarius for the hydrolysis of palm oil mill effluent (POME). The hydrolysate was used for the production of biohydrogen gas and enzyme assays were carried out to determine the productivities/activities of lignin peroxidase, laccase, xylanase, endoglucanase and $\beta$-glucosidase in spent mushroom substrate. Further, the enzyme cocktails were concentrated for the hydrolysis of POME. Central composite design of response surface methodology was performed to examine the effects of enzyme loading, incubation time and $\mathrm{pH}$ on the reducing sugar yield. Productivities of the enzymes for xylanase, laccase, endoglucanase, lignin peroxidase and $\beta$-glucosidase were $2.3,4.1,14.6,214.1$, and $915.4 \mathrm{U} \mathrm{g}^{-1}$, respectively. A maximum of $3.75 \mathrm{~g} / \mathrm{l}$ of reducing sugar was obtained under optimized conditions of $15 \mathrm{~h}$ incubation time with $10 \%$ enzyme loading $(\mathrm{v} / \mathrm{v})$ at a $\mathrm{pH}$ of 4.8 , which was consistent with the predicted reducing sugar concentration ( $3.76 \mathrm{~g} / \mathrm{l})$. The biohydrogen cumulative volume (302.78 $\left.\mathrm{ml} \mathrm{H}_{2} \cdot \mathrm{L}^{-1} \mathrm{POME}\right)$ and $\mathbf{8 3 . 5 2 \%}$ biohydrogen gas were recorded using batch fermentation which indicated that the enzymes of spent mushroom substrate can be utilized for hydrolysis of POME.

Keywords: Pleurotus pulmonarius, edible mushroom, enzymatic hydrolysis, palm oil mill effluent, spent mushroom substrate, biohydrogen

Received: March 10, 2021 Accepted: April 27, 2021

First published online: April 29, 2021

*Corresponding author Phone/Fax: +60379676753

E-mail: tanyeeshin@um.edu.my

pISSN 1017-7825 eISSN 1738-8872

Copyright(C) 2021 by The Korean Society for Microbiology and Biotechnology

\section{Introduction}

Pleurotus pulmonarius (Fries) Quélet is one of the top commercially cultivated mushrooms in the world due to its wide adaptability to the natural environment and ability to utilize a range of agroresidues as substrate by secreting a broad array of ligninolytic and cellulolytic enzymes [1]. However, the industry has struggled to manage and discard the spent mushroom substrate (SMS). Singh et al. [2] reported that around $800 \mathrm{~g}$ of SMS is discarded as waste for every $200 \mathrm{~g}$ of mushroom produced. The inefficient practices of disposal and management of the wastes has spurred studies on utilizing the biomass for production of value-added products [3].

SMS contains high organic matter, mineral nutrients and enzymes [4]. The common ways of recycling SMS include transformation into biofuel [5], biofertilizer [6-8] and reducing sugar for the fermentation process [9, 10]. The study showed that SMS pretreated with dilute acid and alkaline reagents could improve cellulose degradation into sugar. Thus, SMS extract could be used as a potential feedstock for reducing sugar production and minimize environmental problems. Currently, there are several reports on the applications of enzymes from SMS [11-13].

Thus, SMS could be a potential source of lignocellulolytic enzymes to hydrolyze palm oil mill effluent (POME) which has been classified as one of the major causes of water pollution [14]. Raw POME is produced from a combination of sterilizer condensate, separator sludge and hydrocyclone wastewater in a proportion of 9:15:1, respectively [15].

Conversion of POME into value-added products has been identified as an alternative method of waste treatment. Moreover, POME is recognized as one of the lignocellulosic biomass substrates in the biofuel industry for conversion into fermentable sugars [16]. The sugars can be utilized for a higher value feedstock to produce biogas and biofuel. High-cost commercial enzymes have been used for POME hydrolysis which converts the organic substances in POME into monomeric sugars [17-19]. However, studies on the potential use of enzymes from SMS for the hydrolysis of POME have not been explored. Further, the high concentrations of lipid, minerals, 
carbohydrates, protein, and nitrogenous compounds in POME make it a suitable substrate for biohydrogen production [20].

Hydrogen production from biomass has been a captivating substitute for fossil fuels while hydrogen is known as the cleanest renewable energy source with zero carbon emission [21]. Many studies have been conducted on the biohydrogen production from POME involving different experimental conditions such as pre-treatment of POME using Clostridium butyricum [22], application of a granular sludge system and fixed film reactor [23], and two-stage thermophilic and mesophilic fermentation condition [24].

Hence, the aim of this study was to hydrolyze POME using enzymes extracted from the SMS of P. pulmonarius. Three factors that might affect the hydrolysis rate (viz. incubation time, enzyme loading and $\mathrm{pH}$ ) were analyzed to examine the optimum conditions to hydrolyze lignocellulolytic components in POME into simple sugar. A central composite design (CCD) in response surface methodology (RSM) was chosen for the optimization of hydrolysis [25]. Finally, a validation batch study to examine the feasibility of utilizing the hydrolysate for biohydrogen production was conducted.

\section{Materials and Methods \\ Enzymes Extraction}

P. pulmonarius mushroom substrate bags were collected from Nas Agro Farm in Sepang, Selangor, Malaysia. Initially, 11-week-old inoculated substrate bags were randomly collected. The substrates of five bags were mixed manually. Then, three replicate samples were randomly chosen for extraction. The extraction was conducted by adding $20 \mathrm{~g}$ of SMS to $100 \mathrm{ml}$ of tap water ( $\mathrm{pH} 4.0$ ) in a $250 \mathrm{ml}$ Erlenmeyer flask [2]. The mixture was incubated in a shaking incubator (Daihan Labtech Co., Singapore) with a speed of $150 \mathrm{rpm}$ for one hour at $4^{\circ} \mathrm{C}$. The supernatant of crude enzymes was isolated from the solids by centrifugation at $9,000 \times g$ for $20 \mathrm{~min}$ and stored at $-20^{\circ} \mathrm{C}$ before enzyme assays. The crude enzymes were concentrated using a freeze dryer (Alpha 1-4 LDplus, Christ) and the concentration was fixed at $100 \mathrm{mg} / \mathrm{ml}$ for hydrolysis of POME. The enzyme powder was placed in a sealed container and stored in a $4^{\circ} \mathrm{C}$ fridge before further hydrolysis. Productivities of the concentrated enzymes were measured and reported as $\mathrm{U} / \mathrm{g}$ of the substrate [2].

All the enzyme activities in this study were measured by a UV-160A spectrophotometer (Shimadzu). The enzyme activity unit (U) was defined as the amount of enzyme required to produce $1 \mu$ mole of product $/ \mathrm{min}$. Meanwhile for laccase, enzyme activity unit (U) was defined as the amount of enzyme producing one-unit change in absorbance/min. The result of this study was reported in terms of productivity based on the number of units obtained per gram (U/g) of the SMS used [2].

\section{Measurement of SMS Enzyme Activity}

Lignin peroxidase (LiP) activity was determined using the method described by Have et al. [26]. The reaction mixture consisted of $0.2 \mathrm{ml}$ crude enzyme, $2.4 \mathrm{ml}$ of $100 \mathrm{mM}$ sodium tartrate buffer ( $\mathrm{pH} 3.0$ ) and $0.2 \mathrm{ml}$ of $2 \mathrm{mM}$ veratryl alcohol. Veratraldehyde was used as the standard. The experiment was started by adding $0.2 \mathrm{ml}$ of freshly prepared $0.5 \mathrm{mM} \mathrm{H}_{2} \mathrm{O}_{2}$ (final concentration). The absorbance reading was recorded at $310 \mathrm{~nm}$ after 5 min of incubation.

Laccase assay was measured using the method as described by Harkin and Obst; Leonowicz and Grzywnowicz $[27,28]$. The reaction mixture contained $0.5 \mathrm{ml}$ of the crude enzyme, $3.0 \mathrm{ml}$ of sodium citrate buffer $(\mathrm{pH} 4.8)$ and the substrate used was $0.5 \mathrm{ml}$ of $0.1 \mathrm{mM}$ syringaldazine in ethanol $(50 \%, \mathrm{w} / \mathrm{v})$. The activity of laccase was examined by recording the absorbance at $525 \mathrm{~nm}$. The quantity of enzyme releasing one unit of absorbance change $\mathrm{min}^{-1} \mathrm{~g}^{-1}$ of the substrate represents one unit of activity. Xylanase activity was measured using the method of Bailey et al. [29]. The reaction mixture consisted of $0.2 \mathrm{ml}$ of crude enzyme and $1.8 \mathrm{ml}$ of substrate. The solution was mixed and incubated at $40^{\circ} \mathrm{C}$ for $1 \mathrm{~h}$ in water bath with moderate shaking. The amount of sugars liberated was quantified by dinitrosalicylic acid (DNS) method [30]. Xylose was used as the standard. The activity was defined as the number of xylanases needed to produce $1 \mu$ mole of xylose $\min ^{-1}$ at a wavelength of $\lambda=575 \mathrm{~nm}$. Endoglucanase activity was measured followed the method by Kim et al. [31]. Sodium salt of carboxymethyl cellulose solution with medium viscosity $(1 \% \mathrm{w} / \mathrm{v})$ was used as the substrate. Glucose was used as the standard. The reaction comprised $1.8 \mathrm{ml}$ of substrate and $0.2 \mathrm{ml}$ of the crude enzyme. The solution was agitated adequately in a water bath and incubated at $40^{\circ} \mathrm{C}$ for 30 minutes with gentle agitation. The reducing sugar liberated was quantified using the DNS method [30]. The activity was defined as the quantity of endoglucanase required to produce $1 \mu$ mole of glucose $\min ^{-1}$ at a wavelength of $\lambda=575 \mathrm{~nm}$. $\beta$-glucosidase activity was determined following the method described by Kim et al. [31]. The substrate used was $0.5 \mathrm{mM}$ p-nitrophenyl- $\beta$-D-glucopyranoside in $50 \mathrm{mM}$ sodium citrate buffer ( $\mathrm{pH} 4.8$ ). The reaction mixture consists of $1.8 \mathrm{ml}$ of substrate and $0.2 \mathrm{ml}$ of crude enzyme. Each of the test tubes was protected using aluminium paper since the released p-nitrophenol is photosensitive. The solution was incubated at $40^{\circ} \mathrm{C}$ for $30 \mathrm{~min}$ in a water bath with gentle agitation. The incubation was stopped by the addition of $2.0 \mathrm{ml}$ of $1 \mathrm{M} \mathrm{Na}_{2} \mathrm{CO}_{3}$. The amount of p-nitrophenol liberated was calculated using $\mathrm{p}$-nitrophenol as the standard. The activity was defined as the number of $\beta$-glucosidases needed to produce $1 \mu$ mole of $\mathrm{p}$-nitrophenol $\mathrm{min}^{-1} \mathrm{~g}^{-1}$ of the substrate at a wavelength of $\lambda=400 \mathrm{~nm}$.

\section{Statistical Analysis}

Analysis of variance (ANOVA) was done with means of triplicate values of enzyme productivities and Duncan's Multiple Range Test was employed to determine significant differences between the three means at $95 \%$ least significant difference $(p<0.05)$. 


\section{Characteristics of the Palm Oil Mill Effluent}

POME was collected from Jugra Palm Oil Mill in Banting, Selangor, Malaysia after the acidification process [32]. The POME was set aside at room temperature for $20 \mathrm{~min}$ to settle the solids and the supernatant was extracted and used as pre-settled POME [25]. Before enzymatic hydrolysis, the pre-settled POME was preserved at $4^{\circ} \mathrm{C}$ in a cold room. The $\mathrm{pH}$ of the pre-settled POME was 4.99 , with chemical oxygen demand of $27,000-$ $28,000 \mathrm{mg} / \mathrm{l}$. The total nitrogen and protein recorded were $0.11 \%$ and $0.70 \%$, respectively. Additionally, the concentration of the reducing sugar in POME was recorded at $0.77 \mathrm{~g} / \mathrm{l}$. Meanwhile, POME sludge collected from an anaerobic pond of the same palm oil mill was used as inoculum for biohydrogen production [32].

\section{Experimental Design for Optimization}

The POME hydrolysis was carried out in an Erlenmeyer flask $(250 \mathrm{ml})$ with a screw cap. The mixture consists of $10 \%(\mathrm{v} / \mathrm{v})$ concentrated enzyme loading $(10 \mathrm{ml}$ enzyme $/ 100 \mathrm{ml}$ of POME). The preliminary experiments (unpublished data) showed that enzymes from SMS were able to hydrolyze POME. Thus, Design-Expert software (Stat-Ease Inc., USA; Version 6.0.7) was used for the optimization of hydrolysis in terms of experimental design, data analysis, and graphical study of the data. Overall 20 experiments were conducted to optimize the process parameters. The concentrated enzymes $(0 \%, 5 \%, 10 \%)$ were inoculated into the POME in the rotary shaker under different incubation times $(0,12,24 \mathrm{~h})$. The mixture was adjusted to different conditions of $\mathrm{pH}$ value $(4.8,5.4,6.0)$ with $1 \mathrm{~N} \mathrm{HCL}$ or $1 \mathrm{~N} \mathrm{NaOH}$ [26]. The significance of the three factors was determined by the ANOVA. Equation (1) was used to obtain the coefficients of the polynomial model:

$$
\mathrm{Y}=\beta_{0}+\beta_{i} x_{i}+\beta_{j} x_{j}+\beta_{i i} x_{i}^{2}+\beta_{j j} x_{j}^{2}+\beta_{i j} x_{i} x_{j}+\ldots
$$

where $\mathrm{Y}$ is the predicted response for reducing sugar yield, $\beta$ is the regression, $i$ is linear and $j$ is a quadratic coefficient, respectively. A 3D surface plot displayed the effect of the independent factors on the response. The significance of the second-order equation model was measured by a significant $F$-value and an insignificant lackof-fit $F$-value. The estimated optimum value was verified by an analysis using the chosen optimum value of the three factors.

\section{Batch Fermentation for Biohydrogen Production}

Batch fermentation for biohydrogen production was conducted according to Khaleb et al. [19] with modification. The POME sludge was used as inoculum for the hydrogen fermentation process with the pre-settled POME as the control and the hydrolyzed POME as the substrate. The study batch was conducted by a working amount of $100 \mathrm{ml}$ using $156 \mathrm{ml}$ serum bottles [33]. The fermentation process was started by adding $20 \%(\mathrm{v} / \mathrm{v})$ of POME sludge to $80 \%(\mathrm{v} / \mathrm{v})$ of the POME hydrolysate. Following that, an anaerobic condition was created by sparging nitrogen gas for $10 \mathrm{~min}$ during the start-up of the fermentation. The fermentation process was performed in a mesophilic condition $\left(37^{\circ} \mathrm{C}\right)$ with an initial $\mathrm{pH}$ of 5.5 and agitation maintained at $150 \mathrm{rpm}$ for $24 \mathrm{~h}$. The gas chromatography (Model Perkin Elmer, Autosystem GC) was provided with a thermal conductivity

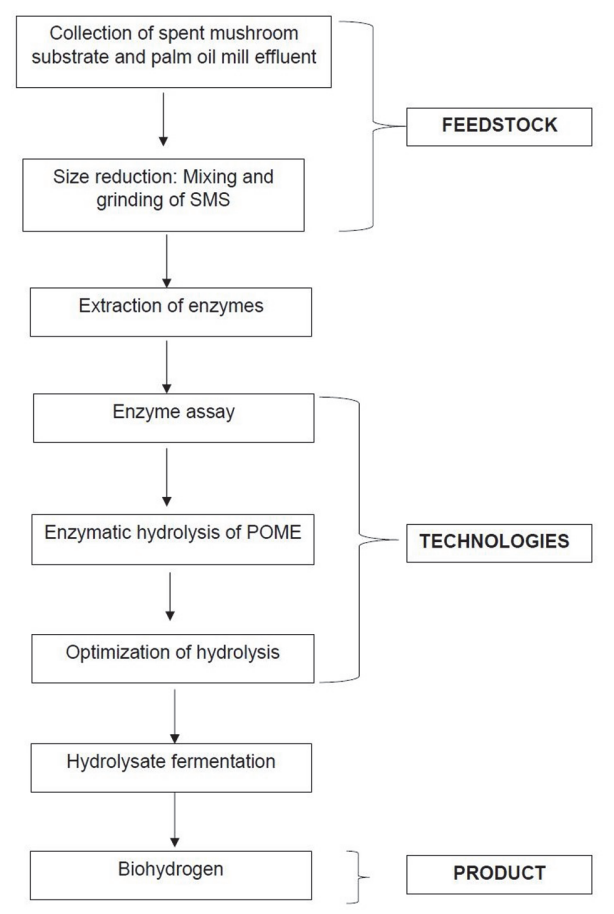

Fig. 1. Process flow for the hydrolysis of POME. 
detector (TCD) and a packed GC column (Supelco with 40/80 carboxen 1000, MR2924D; 10' × 18') was utilized to quantify the biogas composition [32]. Fig. 1 shows the process flow from enzyme extraction to the batch biohydrogen production in this study.

\section{Results and Discussions}

Analysis of Enzyme Assays

Cultivated P. pulmonarius has two phases of production growth (mycelium and fruiting body stage). During the vegetative stage, the mycelia secrete enzymes to degrade celluloses and lignin in lignocellulosic biomass. During the reproductive stage, the fruiting body's formation generally lasts for two to three days superseded by a resting phase of about ten days before the second cycle of the fruiting stage. Generally, the P. pulmonarius fruit bodies were harvested over five to six cycles before the mushroom bags were deposited as agricultural wastes. The SMS from the eleventh week was selected based on the enzyme profiles (unpublished data for the enzyme profiles from the first week to tenth week of SMS). Enzyme profiles of this study illustrated a periodical bell-shaped pattern of all the enzyme productivities of $P$. pulmonarius, comparable to other white rot fungi such as Pleurotus ostreatus [34] and Grifola frondosa [35].

The enzyme activities and productivities of the SMS were measured and presented in Table 1. $\beta$-glucosidase productivity in this study $(915.39 \mathrm{U} / \mathrm{g})$ was 10.2 -folds higher than the $\beta$-glucosidase productivity of Pleurotus sajor-caju after twelve weeks' inoculation into mushroom bags $(89.73 \mathrm{U} / \mathrm{g})$ reported by Singh et al. [36]. This could be due to the use of concentrated enzymes in this study as compared to the study by Singh et al. [36], which used crude enzyme extract. Meanwhile, laccase productivity in this study $(4.41 \mathrm{U} / \mathrm{g})$ was comparable to laccase productivity of SMS $(3.0 \mathrm{U} / \mathrm{g}$ ) extracted from P. pulmonarius after the second harvest in a study reported by Ariff $e t$ al. [13]. This could be an indication of mycelia accumulation during the vegetative stage of growth.

The hydrolysis of cellulose is restricted due to the high cost of commercial cellulase enzymes [37]. Normally, the price of commercial enzymes constitutes about $80 \%$ of the final cost of hydrolysis of agroresidues to fermentable sugars [38]. Since the management of SMS in bulk will require high storage and transportation costs, mushroom growers might do well to consider their SMS as valuable feedstocks for conversion or extraction into value-added products $[39,40]$. Efficient hydrolysis strategies have been developed to increase enzyme production while reducing the operation cost [41].

Hence, this study showed that SMS of $P$. pulmonarius could be a good source of extracellular enzymes but requires an economical method of extracting the enzymes from the SMS. However, enzyme extraction on a large scale might not be feasible economically if it requires a cold environment for one hour. Application of a homogenizer at room temperature can be an alternative for extraction as the enzymes were able to diffuse into the extraction medium within a shorter time. Thus, the $\mathrm{pH}$ tolerance and temperature tolerance of the five enzymes in this study were not determined as the main objective here was to test the feasibility of using enzymes extracted from locally collected SMS for the hydrolysis of POME.

\section{Optimization of Enzymatic Hydrolysis}

POME contains a large amount of insoluble suspended solids and organic matter. POME has potential as a substrate for generating bioenergy, especially biogas due to high organic compounds [42]. Since POME is readily available from the mills, it could served as best source for renewable energy. Therefore, an optimum level of biodegradable sugars from the POME could be obtained with a suitable hydrolysis step [43]. RSM analysis could be applied as it provides visual responses for interaction among the experimental factors [44]. Furthermore, a matrix of CCD in RSM requires only a minimal number of experiments while yielding systematic results, and less reagent usage [45]. According to Neoh et al. [46], CCD consists of a two-level factorial design with center and axial points that would provide the optimum result over a specified range of variables. The matrix for the CCD and outcomes for the optimization of reducing sugar yield are displayed in Table 2. The highest reducing sugar yield $(3.82 \mathrm{~g} / \mathrm{l})$ was obtained from hydrolysis using $10 \%$ enzyme loading at pH 5.4 and the lowest sugar yield $(0.90 \mathrm{~g} / \mathrm{l})$ was obtained from hydrolysis without enzyme added to the POME. Khaw and Ariff [18] suggested that an increase in saccharification rate and sugar yield was found proportional to increasing enzyme concentration.

Results acquired from the optimization experiments were analyzed using ANOVA (Table 3 ). The model's $F$ value of 38.41 demonstrated that the model was significant $(p<0.0001)$ and there was $0.01 \%$ chance that the model's $F$-value might arise considering noise. The $p$-value for the models A, B, and $\mathrm{A}^{2}$ were significant, $p<0.0500$. The model is applicable and could be approved since the coefficient of determination $\left(\mathrm{R}^{2}\right)$ of the model was 0.9719 , which conveys model competency.

Equation 2 comprises 1 offset term, 3 linear terms, 3 quadratic terms and 3 interactions, represents the quadratic model for the response. The equation shows a valid correlation amongst the parameters studied and the

Table 1. Enzyme activities and productivities from SMS of $P$. pulmonarius. The results are the mean of three samples.

\begin{tabular}{lcc}
\hline \multicolumn{1}{c}{ Enzymes } & Activities $(\mathrm{U} / \mathrm{ml})$ & Productivities $(\mathrm{U} / \mathrm{g})$ \\
\hline Lignin Peroxidase & $42.82 \pm 0.26$ & $214.14 \pm 1.31$ \\
Laccase & $0.82 \pm 0.01$ & $4.14 \pm 0.05$ \\
Xylanase & $0.45 \pm 0.02$ & $2.25 \pm 0.11$ \\
Endoglucanase & $2.91 \pm 0.52$ & $14.56 \pm 2.61$ \\
$\beta$-glucosidase & $183.08 \pm 10.42$ & $915.39 \pm 52.08$
\end{tabular}


Table 2. The CCD matrix and optimization results.

\begin{tabular}{|c|c|c|c|c|}
\hline \multirow[b]{2}{*}{ Run } & \multicolumn{3}{|c|}{ Variables } & \multirow{2}{*}{$\begin{array}{c}\text { Response } \\
\begin{array}{c}\text { Reducing sugar } \\
(\mathrm{g} / \mathrm{l})\end{array}\end{array}$} \\
\hline & $\begin{array}{c}\text { A: } \\
\text { Time (h) }\end{array}$ & $\begin{array}{c}\text { B: } \\
\text { Enzyme loading }(\%, v / v)\end{array}$ & $\begin{array}{l}\mathrm{C}: \\
\mathrm{pH}\end{array}$ & \\
\hline 1 & 12 & 5 & 5.4 & 2.91 \\
\hline 2 & 12 & 5 & 5.4 & 2.92 \\
\hline 3 & 12 & 5 & 5.4 & 2.90 \\
\hline 4 & 24 & 10 & 6.0 & 3.44 \\
\hline 5 & 0 & 0 & 4.8 & 0.90 \\
\hline 6 & 24 & 5 & 5.4 & 2.56 \\
\hline 7 & 12 & 5 & 4.8 & 2.79 \\
\hline 8 & 0 & 10 & 4.8 & 2.90 \\
\hline 9 & 12 & 5 & 6.0 & 2.63 \\
\hline 10 & 0 & 5 & 5.4 & 1.66 \\
\hline 11 & 0 & 10 & 6.0 & 2.49 \\
\hline 12 & 12 & 5 & 5.4 & 2.86 \\
\hline 13 & 24 & 0 & 4.8 & 0.97 \\
\hline 14 & 12 & 10 & 5.4 & 3.82 \\
\hline 15 & 12 & 5 & 5.4 & 2.89 \\
\hline 16 & 12 & 5 & 5.4 & 2.55 \\
\hline 17 & 0 & 0 & 6.0 & 0.90 \\
\hline 18 & 24 & 0 & 6.0 & 0.95 \\
\hline 19 & 24 & 10 & 4.8 & 3.24 \\
\hline 20 & 12 & 0 & 5.4 & 1.16 \\
\hline
\end{tabular}

data acquired appeared well-suited to the second-order polynomial in comparison to other models:

$$
\mathrm{Y}(\mathrm{g} / \mathrm{l})=2.79+0.23 \mathrm{~A}+1.10 \mathrm{~B}-0.039 \mathrm{C}-0.60 \mathrm{~A}^{2}-0.22 \mathrm{~B}^{2}-4.545 \mathrm{E}-003 \mathrm{C}^{2}+0.15 \mathrm{AB}+0.074 \mathrm{AC}-0.024 \mathrm{BC}
$$

where the coded variable Y symbolizes concentration of the reducing sugar, whilst $\mathrm{A}, \mathrm{B}$, and $\mathrm{C}$ represent time, enzyme loading and $\mathrm{pH}$ respectively.

The 3D contour plots of the model for variation in reducing sugar yield, as a function of time (A) and enzyme loading (B) at three different $\mathrm{pH}$ values $(4.8,5.4$, and 6.0) was shown in Fig. 2. From Fig. 2A, an increase of reducing sugar concentration would be acquired with increase of the incubation time until $12 \mathrm{~h}$ while increasing enzyme loading from 0 to $10 \%(\mathrm{v} / \mathrm{v})$. The hydrolysis was characterized by an initial logarithmic stage indicating the rapid production of reducing sugars [18]. A highest reducing sugar concentration of $3.76 \mathrm{~g} / \mathrm{l}$ would be acquired at $\mathrm{pH}$ value 4.8 when a high amount of enzyme loading of $10 \%$ was used with the addition of incubation time of more than $12 \mathrm{~h}$. However, an extended incubation time of more than $18 \mathrm{~h}$ would lead to decrease in reducing sugar yield to $3.03 \mathrm{~g} / \mathrm{l}$, which might be due to the presence of cellulase inhibitors that prevent further cellulose conversion into sugar [47].

Table 3. ANOVA acquired from the optimization hydrolysis of POME.

\begin{tabular}{|c|c|c|c|c|c|c|}
\hline Source & Sum of square & $\mathrm{DF}$ & Mean square & F value & Prob $>F$ & Remarks \\
\hline Model & 15.81 & 9 & 1.76 & 38.41 & $<0.0001$ & Significant \\
\hline A & 0.53 & 1 & 0.53 & 11.67 & 0.0066 & Significant \\
\hline B & 12.12 & 1 & 12.12 & 265.09 & $<0.0001$ & Significant \\
\hline $\mathrm{C}$ & 0.02 & 1 & 0.02 & 0.33 & 0.5769 & Not significant \\
\hline $\mathrm{A}^{2}$ & 1.01 & 1 & 1.01 & 21.98 & 0.0009 & Significant \\
\hline $\mathrm{B}^{2}$ & 0.14 & 1 & 0.14 & 3.03 & 0.1122 & Not significant \\
\hline$C^{2}$ & 5.682E-005 & 1 & $5.682 \mathrm{E}-005$ & $1.243 \mathrm{E}-003$ & 0.9726 & Not significant \\
\hline$A B$ & 0.17 & 1 & 0.17 & 3.74 & 0.0818 & Not significant \\
\hline $\mathrm{AC}$ & 0.04 & 1 & 0.04 & 0.95 & 0.3523 & Not significant \\
\hline $\mathrm{BC}$ & $4.513 \mathrm{E}-003$ & 1 & $4.513 \mathrm{E}-003$ & 0.10 & 0.7599 & Not significant \\
\hline Residual & 0.46 & 10 & 0.05 & & & \\
\hline Lack of fit & 0.36 & 5 & 0.07 & 3.49 & 0.0983 & Not significant \\
\hline Pure error & 0.10 & 5 & 0.02 & & & \\
\hline Total & 16.26 & 19 & & & & \\
\hline SD & 0.21 & C.V. & 9.02 & $\mathrm{R}^{2}$ & 0.9719 & \\
\hline \multirow[t]{3}{*}{ Mean } & 2.37 & PRESS & 3.48 & Adj. $R^{2}$ & 0.9466 & \\
\hline & & & & Pred. $\mathrm{R}^{2}$ & 0.7858 & \\
\hline & & & & Adeq. Prec. & 19.740 & \\
\hline
\end{tabular}

${ }^{\star} \mathrm{DF}$ : degree of freedom; SD: standard deviation; C.V.: coefficient of variation; PRESS: prediction error sum of squares; Adj. R²: adjusted R-squared; Pred. $\mathrm{R}^{2}$ : predicted R-squared; Adeq. Precision: adequate precision 
A

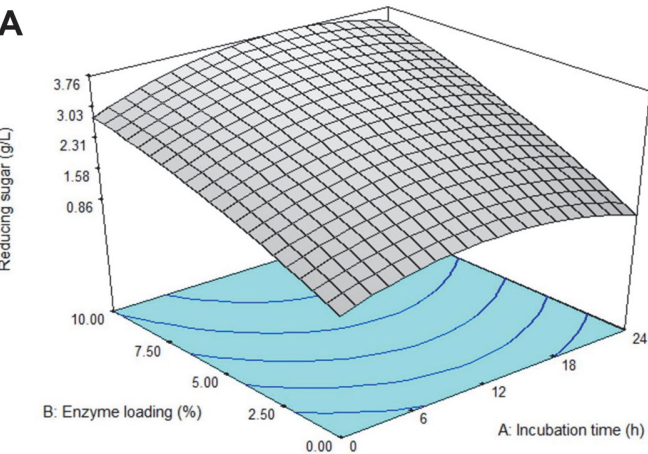

C

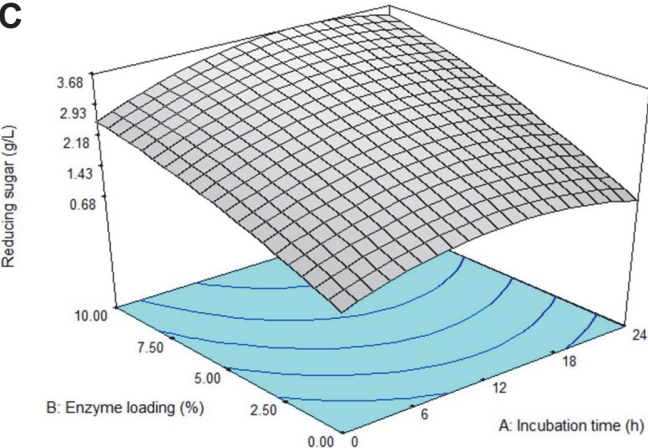

B

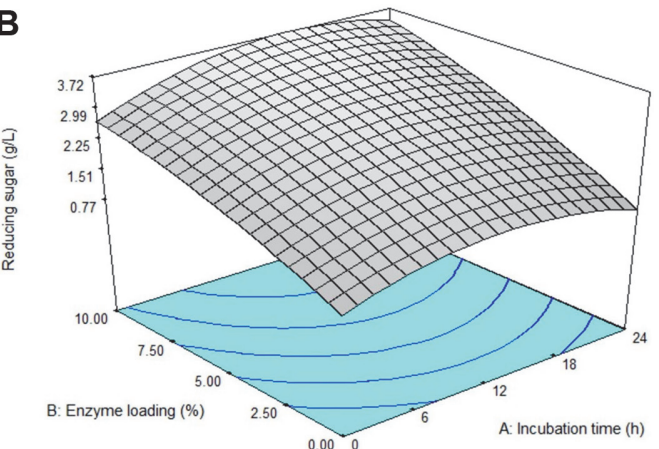

Fig. 2. Response surface plot of reducing sugar yield representing the effect of incubation time and enzyme loading. (A) $\mathrm{pH}$ 4.8. (B) $\mathrm{pH}$ 5.4. (C) $\mathrm{pH}$ 6.0.

A total of $3.72 \mathrm{~g} / \mathrm{l}$ reducing sugar would be acquired when $\mathrm{pH} 5.4$ was used at the center point values between $15 \mathrm{~h}$ and $10 \%$ of enzyme loading (v/v) (Fig. 2B). As the $\mathrm{pH}$ value increased to $\mathrm{pH} 6.0,3.68 \mathrm{~g} / \mathrm{l}$ reducing sugar was achieved at the high amount of enzyme loading (10\%) and between 12 to $18 \mathrm{~h}$ incubation time (Fig. 2C). Certain factors were recorded that could affect enzymatic hydrolysis of the POME, concurrently reducing sugar yield. Zhu et al. [48] explained that the structural features of substrates, solids loading, enzyme loading, and hydrolysis period greatly affected the rate of enzymatic hydrolysis.

Mun et al. [49] recorded a total of $22.8 \mathrm{~g} / \mathrm{l}$ reducing sugar when the POME solid was hydrolyzed at $12 \mathrm{~h}$ using mixed cellulase enzymes (Table 4). The sugar yield by Mun et al. [49] was higher compared to this study probably due to the pretreatment of POME solid using sulfuric acid. The dilute sulfuric acid pretreatment of lignocellulosic biomass could increase the access to the substrate by enzymes [50]. Khaw and Ariff [18] recorded a high production of reducing sugar from hydrolysis of POME solid $(9.26 \mathrm{~g} / \mathrm{l})$ when a Novozyme/Celluclast ratio of 0.60 was used, probably due to the high proportion of cellulase enzyme combination and enzyme dosage. Meanwhile, Silvamany et al. [16] reported higher reducing sugar yield after hydrolysis of POME liquid compared to this study possibly due to the use of commercial cellulase enzymes. Silvamany et al. [16] also reported that the reducing sugar from POME hydrolysis remained constant after $24 \mathrm{~h}$ indicating the completion of saccharification process. The differences in reducing sugar might be due to the quality of fresh fruit bunches and the efficiency of the machines used during the extraction process. Pandiyan et al. [51] discovered enzymatic hydrolysis of alkaline pretreated Parthenium sp. released a total reducing sugar of $85.8 \%$. In another study, the hydrolysis of oil palm trunk by crude enzymes from Aspergillus fumigatus released $13.15 \mathrm{~g} / \mathrm{l}$ of reducing sugar [52]. The variations in the yield of

Table 4. Comparison of sugar yield after enzymatic hydrolysis of POME.

\begin{tabular}{|c|c|c|c|c|c|}
\hline Enzyme & POME & Pretreatment & Condition & Sugar yield (g/l) & Reference \\
\hline $\begin{array}{l}\text { Crude mixture from } \\
\text { Aspergillus niger EB5 } \\
\text { and Trichoderma sp. EB6 }\end{array}$ & Solid & $\begin{array}{c}0.5 \%(\mathrm{v} / \mathrm{v}) \\
\text { sulfuric acid }\end{array}$ & $\begin{array}{c}12 \mathrm{~h} \\
50^{\circ} \mathrm{C} \\
\mathrm{pH} 5.0\end{array}$ & 22.80 & [49] \\
\hline $\begin{array}{l}\text { Combination of Celluclast 1.5L } \\
\text { and Novozyme } 188\end{array}$ & Solid & None & $\begin{array}{c}6 \mathrm{~h} \\
40^{\circ} \mathrm{C} \\
\mathrm{pH} 5.0\end{array}$ & 9.26 & [18] \\
\hline $\begin{array}{l}\text { Combination of Celluclast 1.5L, } \\
\text { Novozyme } 188 \text { and Viscozyme-L }\end{array}$ & Liquid & None & $\begin{array}{c}48 \mathrm{~h} \\
50^{\circ} \mathrm{C} \\
\mathrm{pH} 4.8\end{array}$ & $\begin{array}{l}\text { Centrifugal waste: } 34.30 \\
\text { Sterilizer condensate: } 6.50\end{array}$ & [16] \\
\hline $\begin{array}{l}\text { Crude enzymes from spent } \\
\text { mushroom substrate }\end{array}$ & Liquid & None & $\begin{array}{c}12 \mathrm{~h} \\
50^{\circ} \mathrm{C} \\
\text { pH } 5.4\end{array}$ & 3.82 & This study \\
\hline
\end{tabular}




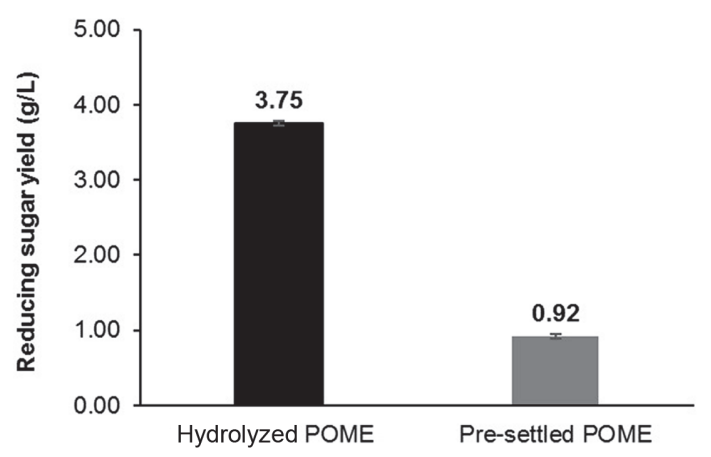

Fig. 3. Reducing sugar yield of hydrolyzed POME and pre-settled POME in the verification experiment.

reducing sugar were possibly contributed by the variety of chemical content in biomass and pretreatment conditions [53]. The prediction was that the hydrolysis rate of POME would be highest at $15 \mathrm{~h}$ of incubation. This might be due to the delignification and decrystallization of substances in POME and the increase in enzymes catalytic activities. As the time extended, the enzyme active sites might have decreased, and thus decrease the hydrolysis rate [54]. An optimum reducing sugar of $3.76 \mathrm{~g} / \mathrm{l}^{-1}$ was estimated with $15 \mathrm{~h}$ of incubation time, at $10 \%$ enzyme loading $(\mathrm{v} / \mathrm{v})$ and $\mathrm{pH}$ value of 4.8 . As for the verification of the optimized condition, hydrolysis of POME released $3.75 \mathrm{~g} /$ lof total reducing sugar, which was consistent with the estimated value (Fig. 3). Hence, the model was suitable to predict the optimal levels of the experiment variables.

Thus, enzymatic hydrolysis of POME using enzymes from SMS is feasible to produce fermentable sugar considering this process does not requires specialized material in the equipment and can be performed with low energy consumption [18].

\section{Batch Biohydrogen Production}

After $24 \mathrm{~h}$ of batch fermentation by POME sludge, a maximum biohydrogen production $\left(302.78 \mathrm{ml} \mathrm{H} \cdot \mathrm{L}^{-1}\right.$ POME) was recorded from the hydrolyzed POME which was 23-folds higher than the pre-settled POME (13.38 $\mathrm{ml} \mathrm{H}_{2} \cdot \mathrm{L}^{-1} \mathrm{POME}$ ) (Table 5). The low biohydrogen production from the pre-settled POME as compared to hydrolyzed POME might be due to the high metabolite accumulation in the pre-settled POME. However, analysis of soluble metabolites, organic acids produced during hydrolysis, and particular analysis on biohydrogen production during the fermentation process was excluded in this study as these were not the main scope of this study. Nevertheless, the percentage of hydrogen and carbon dioxide produced in this study was comparable to Fang and Liu [55], where the hydrogen content ensued an opposite trend of carbon dioxide at the $\mathrm{pH}$ value between 4.0 to 7.0 .

Fermentative biohydrogen yield is influenced by several aspects including $\mathrm{pH}$, temperature, substrate concentration and the amount of inoculum feed [56]. The production of biohydrogen in this study was 14-folds lower than the biohydrogen production recorded by Kamal et al. [22] where the POME was pre-treated with acid and heat which could be hazardous, poisonous, and risky in a laboratory setting. Moreover, the acid-heat pretreatment method is an expensive process and might have formed inhibitory compounds such as furfural [57]. The biohydrogen production in this study $\left(302.78 \mathrm{ml} \mathrm{H} \cdot \mathrm{L}^{-1} \mathrm{POME}\right)$ was lower than the biohydrogen production reported by Khaleb et al. [19], which was $1,439 \mathrm{ml} \mathrm{H}_{2} \cdot \mathrm{L}^{-1}$ of POME (Table 6). The difference might be due to the use of purified and concentrated commercial enzymes (Celluclast 1.5L and Novozyme 188) during the initial POME hydrolysis. This condition led to a higher degree of sugar degradation and higher biohydrogen production. However, this study provides a more economical way to prepare lignocellulolytic enzymes for POME hydrolysis.

In addition, the biohydrogen production in this study was 2-folds higher compared to the study by Garritano et al. [58] that used plant enzyme preparation extracted from dormant castor bean seeds, as well as higher $\mathrm{pH}(\mathrm{pH}$ 6.5) applied during the fermentation process. Fang and Liu's [55] study found that the biohydrogen yield hit the maximum value at $\mathrm{pH}$ of 5.5. This condition was the same as that of Chong et al. [59] where the highest hydrogen output of $3,195 \mathrm{ml} \mathrm{H}{ }_{2} \cdot \mathrm{L}^{-1} \mathrm{POME}$ was released at $\mathrm{pH}$ of 5.5.

Table 5. Outcomes of POME composition after $24 \mathrm{~h}$ of batch fermentation.

\begin{tabular}{lcc}
\hline \multicolumn{1}{c}{ POME composition } & Hydrolyzed POME & Pre-settled POME $^{*}$ \\
\hline Hydrogen cumulative volume $\left(\mathrm{ml} \mathrm{H}_{2} \cdot \mathrm{L}^{-1} \mathrm{POME}\right)$ & $302.78 \pm 13.57$ & $13.38 \pm 3.36$ \\
Hydrogen productivity $\left(\mathrm{ml} \mathrm{H}_{2} \cdot \mathrm{L}^{-1} \mathrm{POME} \mathrm{h}^{-1}\right)$ & $12.62 \pm 0.57$ & $0.56 \pm 0.14$ \\
Percentage of hydrogen $\mathrm{H}_{2}(\%)$ & $83.52 \pm 2.37$ & $36.35 \pm 8.17$ \\
Percentage of carbon dioxide $\mathrm{CO}_{2}(\%)$ & $16.48 \pm 2.37$ & $63.65 \pm 8.17$ \\
Hydrogen volume $(\mathrm{ml})$ & $24.22 \pm 1.09$ & $1.07 \pm 0.27$ \\
Hydrogen production rate $\left(\mathrm{ml} \mathrm{H}_{2} \cdot \mathrm{h}^{-1}\right)$ & $1.01 \pm 0.05$ & $0.04 \pm 0.01$ \\
\hline
\end{tabular}

*Values represent means of three replicate samples. 
Table 6. Comparison in biohydrogen production after fermentation employing POME as a substrate.

\begin{tabular}{|c|c|c|c|c|c|}
\hline $\begin{array}{l}\text { Temp. } \\
\left({ }^{\circ} \mathrm{C}\right), \mathrm{pH}\end{array}$ & Treatment of POME & $\begin{array}{c}\text { Type of } \\
\text { microorganisms }\end{array}$ & $\begin{array}{c}\text { Biohydrogen production } \\
\left(\mathrm{ml} \mathrm{H}_{2} / \mathrm{L} \text { POME }\right)\end{array}$ & $\begin{array}{l}\text { Biohydrogen productivity } \\
\left(\mathrm{ml} \mathrm{H}_{2} / \mathrm{L} \mathrm{POME} / \mathrm{h}\right)\end{array}$ & Reference \\
\hline $37,7.0$ & Acid-heat treatment & Bacteria & 4304.00 & NA & {$[22]$} \\
\hline $37,6.0$ & Enzymatic hydrolysis & Fungal enzyme & 1439.00 & 87.19 & [19] \\
\hline $35,6.5$ & Enzymatic hydrolysis & Plant enzyme & 134.74 & 8.42 & {$[58]$} \\
\hline $37,5.5$ & NA & Bacteria & 3195.00 & 1034 & [59] \\
\hline $37,5.5$ & Enzymatic hydrolysis & Fungal enzyme & 302.78 & 12.62 & This study \\
\hline
\end{tabular}

NA: not available

Most hydrogen is generated from fossil fuels as the demand is increasing worldwide. However, fossil fuel energy has caused obnoxious environmental pollution [19]. The alternative for sustainable hydrogen production is through fermentation. The biological process has several advantages including low sludge formation, low energy demand, lack of unpleasant smell and production of methane due to the efficient degradation of organic compounds by bacteria [60].

Recently, many studies have utilized starch or simple sugars via dark fermentation which is costly for biohydrogen production [61-63]. Thus, the new research trend is to utilize cheap and readily available POME for biohydrogen production [14]. The utilization of this lignocellulosic SMS and POME could promote the agricultural economy, reduce greenhouse gas emissions, and improve energy security [64]. In addition, the mushroom industry produces 24 tons of SMS per month [3] and has been reported to contribute approximately $£ 90$ million to the economy of the Republic of Ireland [65], while securing 3,000 jobs [66]. Nowadays, dried SMS is sold for more than $10 \mathrm{RMB}$ Yuan/50 kg at Sanzhi District for biogas production [67]. Meanwhile, Najafi et al. [68] recorded that one period of SMS production releases biogas energy equal to $277.95 \mathrm{~kW} . \mathrm{h} /$ ton at $35^{\circ} \mathrm{C}$ and $322.84 \mathrm{~kW} \cdot \mathrm{h} /$ ton at $55^{\circ} \mathrm{C}$.

Thus, both SMS and POME are suitable resources for producing value-added products. The results of this study warrant a scale-up of biohydrogen production using hydrolyzed POME.

\section{Conclusion}

The disposal of spent mushroom substrate has been a major issue for mushroom growers worldwide. SMS is either discarded in landfills or directly burnt which cause environmental pollution. Thus, the present study identified the potential of using concentrated enzymes extracted from SMS in the hydrolysis of POME. Using response surface methodology, incubation time and enzyme loading factors had significant effects $(p<0.05)$ on the POME hydrolysis. A total of $3.75 \mathrm{~g} / \mathrm{l}$ reducing sugar was obtained at $15 \mathrm{~h}$ incubation time with $10 \%(\mathrm{v} / \mathrm{v})$ enzyme loading, indicating that the enzymes extracted from SMS could be a renewable resource for hydrolysis of agroresidues. Batch fermentation using hydrolyzed POME (302.78 $\left.\mathrm{ml} \mathrm{H}_{2} \cdot \mathrm{L}^{-1} \mathrm{POME}\right)$ for biohydrogen production yielded 23 times higher volume of biohydrogen compared to non-hydrolyzed pre-settled POME $\left(13.38 \mathrm{ml} \mathrm{H} \cdot \mathrm{L}^{-1}\right.$ POME). The direct utilization of the spent mushroom substrate for enzymatic hydrolysis can be further explored to determine the economics aspects and could be a favorable choice for recovery of biofuel (hydrogen) product. Hydrolysis of POME using enzymes from SMS illustrates a cost-effective upscaling strategy for an economical conversion to reducing sugars.

\section{Acknowledgments}

This research was funded by Postgraduate Research Fund, PPP under grant number PG064-2013B, University of Malaya, Malaysia and Ministry of Education Malaysia (MyBrainSc) Scholarship. The author would like to acknowledge Prof. Dr. Shaliza Ibrahim, Bidattul Syirat Zainal and Wan Nadzirah Meor Abdul Wahab for their contribution in this study.

\section{Conflict of Interest}

The authors have no financial conflicts of interest to declare.

\section{References}

1. Massadeh MI, Modallal N. 2007. Ethanol production from olive mill wastewater (OMW) pretreated with Pleurotus sajor-caju. Energy Fuels 22: 150-154.

2. Singh AD, Vikineswary S, Abdullah N, Sekaran M. 2011. Enzymes from spent mushroom substrate of Pleurotus sajor-caju for the decolourisation and detoxification of textile dyes. World J. Microbiol. Biotechnol. 27: 535-545.

3. Phan CW, Sabaratnam V. 2012. Potential uses of spent mushroom substrate and its associated lignocellulosic enzymes. Appl. Microbiol. Biotechnol. 96: 863-873.

4. Khammuang S, Sarnthima R. 2007. Laccase from spent mushroom compost of Lentinus polychrous Lev. and its potential for remazol brilliant blue R decolorisation. Biotechnol. 6: 408-413.

5. Finney KN, Ryu C, Sharifi VN, Swithenbank J. 2009. The reuse of spent mushroom compost and coal tailings for energy recovery: comparison of thermal treatment technologies. Bioresour. Technol. 100: 310-315.

6. Shitole AV, Gade RM, Bandgar MS, Wavare SH, Belkar YK. 2014. Utilization of spent mushroom substrate as carrier for biocontrol agent and biofertilizer. Bioscan 9: 271-275.

7. Zhu HJ, Sun LF, Zhang YF, Zhang XL, Qiao JJ. 2012. Conversion of spent mushroom substrate to biofertilizer using a stress-tolerant phosphate-solubilizing Pichia farinose FL7. Bioresour. Technol. 111: 410-416. 
8. Zhu HJ, Liu JH, Sun LF, Hu ZF, Qiao JJ. 2013. Combined alkali and acid pretreatment of spent mushroom substrate for reducing sugar and biofertilizer production. Bioresour. Technol. 136: 257-266.

9. Wu S, Lan Y, Wu Z, Peng Y, Chen S, Huang Z, et al. 2013. Pretreatment of spent mushroom substrate for enhancing the conversion of fermentable sugar. Bioresour. Technol. 148: 596-600.

10. Qiao JJ, Zhang YF, Sun LF, Liu WW, Zhu HJ, Zhang Z. 2011. Production of spent mushroom substrate hydrolysates useful for cultivation of Lactococcus lactis by dilute sulfuric acid, cellulase and xylanase treatment. Bioresour. Technol. 102: 8046-8051.

11. Ko HG, Park SH, Ki S, Park HG, Park WM. 2005. Detection and recovery of hydrolytic enzymes from spent mushroom compost of four mushroom species. Folia Microbiol. 50: 103-106.

12. Schimpf U, Schulz R. 2016. Industrial by-products from white-rot fungi production. Part I: generation of enzyme preparations and chemical, protein biochemical and molecular biological characterization. Process Biochem. 51: 2034-2046.

13. Ariff INM, Bahrin EK, Ramli N, Abd-Aziz S. 2017. Direct use of spent mushroom substrate from Pleurotus pulmonarius as a readily delignified feedstock for cellulase production. Waste Biomass Valori. 10: 839-850.

14. Ismail I, Hassan MA, Rahman NAA, Soon CS. 2010. Thermophilic biohydrogen production from palm oil mill effluent (POME) using suspended mixed culture. Biomass Bioenerg. 34: 42-47.

15. Wu TY, Mohammad AW, Jahim JM, Anuar N. 2010. Pollution control technologies for the treatment of palm oil mill effluent (POME) through end-of-pipe processes. J. Environ. Manage 91: 1467-1490.

16. Silvamany H, Harun S, Mumtaz T, Jahim JM. 2015. Recovery of fermentable sugars from palm oil mill effluent via enzymatic hydrolysis. J. Teknol. 77: 115-121.

17. Seong KT, Hassan MA, Ariff AB. 2008. Enzymatic saccharifícation of pretreated solid palm oil mill effluent and oil palm fruit fiber. Pertanika J. Sci. Technol. 16: 157-169.

18. Khaw TS, Ariff AB. 2009. Optimization of enzymatic saccharification of palm oil mill effluent solid and oil palm fruit fibre to fermentable sugars. J. Trop Agric. Fd. Sci. 37: 85-94.

19. Khaleb NA, Jahim JM, Kamal SA. 2012. Biohydrogen production using hydrolysates of palm oil mill effluent (POME). J. Asian Sci. Res. 2: 705-710.

20. Sompong O, Prasertsan P, Karakashev D, Angelidaki I. 2008. Thermophilic fermentative hydrogen production by the newly isolated Thermoanaerobacterium thermosaccharolyticum PSU-2. Int. J. Hydrogen Energ. 33: 1204-1214.

21. Mohammadi P, Ibrahim S, Annuar MSM. 2012. Effects of biomass, COD and bicarbonate concentrations on fermentative hydrogen production from POME by granulated sludge in a batch culture. Int. J. Hydrog. Energy 37: 17801-17808.

22. Kamal SA, Jahim JM, Anuar N, Hassan O, Daud WRW, Mansor MF, et al. 2012. Pre-treatment effect of palm oil mill effluent (POME) during hydrogen production by a local isolate Clostridium butyricum. Int. J. Adv. Sci. Eng. Info. Technol. 2: 54-60.

23. Mohammadi P, Ibrahim S, Mohamad Annuar MS. 2014. High-rate fermentative hydrogen production from palm oil mill effluent in an up-flow anaerobic sludge blanket-fixed film reactor. Chem. Eng. Res. Des. 92: 1811-1817.

24. Krishnan S, Singh L, Sakinah M, Thakur S, Wahid ZA, Alkasrawi M. 2016. Process enhancement of hydrogen and methane production from palm oil mill effluent using two-stage thermophilic and mesophilic fermentation Int. J. Hydrog. Energy 41: 1288812898 .

25. Zainal BS, Zinatizadeh AA, Chyuan OH, Mohd NS, Ibrahim S. 2017. Effects of process, operational and environmental variables on biohydrogen production using palm oil mill effluent (POME). Int. J. Hydrog. Energy 43: 10637-10644.

26. Have RT, Hartmans S, Teunissen PJM, Field JA. 1998. Purification and characterization of two lignin peroxidase isozymes produced by Bjerkandera sp. strain BOS55. FEBS Lett. 422: 391-394.

27. Harkin JM, Obst JR. 1973. Syringaldazine, an effective reagent for detecting laccase and peroxidase in fungi. Experientia. 29: $381-387$.

28. Leonowicz A, Grzywnowicz K. 1981. Quantitative estimation of laccase forms in some white-rot fungi using syringaldazine as a substrate. Enzyme Microb. Technol. 3: 55-58.

29. Bailey MJ, Biely P, Poutanen K. 1992. Interlaboratory testing of methods for assay of xylanase activity. J. Biotechnol. 23: 257-270.

30. Miller GL. 1959. Use of dinitrosalicylic acid reagent for determination of reducing sugar. Anal. Chem. 31: 426-428.

31. Kim DW, Kim TS, Jeong YK, Lee JK. 1992. Adsorption kinetics and behaviors of cellulase components on microcrystalline cellulose. J. Ferment. Bioeng. 73: 461-466.

32. Zainal BS, Akhbari A, Zinatizadeh AA, Mohammadi P, Danaee M, Mohd NS, et al. 2019. UASFF start-up for biohydrogen and biomethane production from treatment of palm oil mill effluent. Int. J. Hydrog. Energy 44: 20725-20737.

33. Choi J, Ahn Y. 2015. Biohydrogen fermentation from sucrose and piggery waste with high levels of bicarbonate alkalinity. Energies 8: $1716-1729$

34. Cho NS, Malarczyk E, Nowak G, Nowak M, Kochmanska-Rdest J, Leonowicz A, et al. 2002. Changes in phenol oxidases and superoxide dismutase during fruit-body formation of Pleurotus on sawdust culture. Mycoscience 43: 267-270.

35. Montoya S, Orrego CE, Levin L. 2012. Growth, fruiting and lignocellulolytic enzyme production by the edible mushroom Grifola frondosa (maitake). World J. Microbiol. Biotechnol. 28: 1533-1541.

36. Singh AD, Abdullah N, Vikineswary S. 2003. Optimization of extraction of bulk enzymes from spent mushroom compost. J. Chem. Technol. Biotechnol. 78: 743-752.

37. Binod P, Janu KU, Sindhu R, Pandey A. 2011. Hydrolysis of lignocellulosic biomass for bioethanol production. Biofuels, pp. 229-250. Elsevier Inc, Academic Press.

38. Hiyama R, Gisusi S, Harada A. 2013. Effect of increased harvests on saccharification ratio of waste mushroom medium from the cultivation of shiitake mushroom (Lentinula edodes). J. Wood Sci. 59: 88-93.

39. Ekşioğlu SD, Acharya A, Leightley LE, Arora S. 2009. Analyzing the design and management of biomass-to-biorefinery supply chain. Comput. Ind. Eng. 57: 1342-1352.

40. Zacchi G, Skoong K. Hahn-Hagerdal B. 1988. Economic evaluation of enzymatic hydrolysis of phenol-pretreated wheat straw. Biotechnol. Bioeng. 32: 460-468.

41. Xu ZH, Bai YL, Xu X, Shi JS, Tao WY. 2005. Production of alkali-tolerant cellulase-free xylanase by Pseudomonas sp. WLUN024 with wheat bran as the main substrate. World J. Microbiol. Biotechnol. 21: 575-581.

42. Aziz NIHA, Hanafiah MM. 2017. The potential of palm oil mill effluent (POME) as a renewable energy source. Acta Scientifica Malaysia 1: 9-11.

43. Wu TY, Mohammad AW, Jahim JM, Anuar N. 2009. A holistic approach to managing palm oil mill effluent (POME): biotechnological advances in the sustainable reuse of POME. Biotechnol. Adv. 27: 40-52.

44. Yunus N, Jahim JM, Anuar N, Abdullah SRS, Kofli NT. 2014. Batch fermentative hydrogen production utilizing sago (Metroxylon sp.) starch processing effluent by enriched sago sludge consortia. Int. J. Hydrog. Energy 39: 19937-19946.

45. Tarley CRT, Silveira G, dos Santos WNL, Matos GD, da Silva EGP, Bezerra MA, et al. 2009. Chemometric tools in electroanalytical chemistry: methods for optimization based on factorial design and response surface methodology. Microchem. J. 92: 58-67.

46. Neoh CH, Yahya A, Adnan R, Majid ZA, Ibrahim Z. 2013. Optimization of decolorization of palm oil mill effluent (POME) by growing cultures of Aspergillus fumigatus using response surface methodology. Environ. Sci. Pollut. R. 20: 2912-2923.

47. Ladeira Ázar RI, Bordignon-Junior SE, Laufer C, Specht J, Ferrier D, Kim D. 2020. Effect of lignin content on cellulolytic saccharification of liquid hot water pretreated sugarcane bagasse. Molecules 25: 623 . 
48. Zhu L, O’Dwyer JP, Chang VS, Granda CB, Holtzapple MT. 2008. Structural features affecting biomass enzymatic digestibility. Bioresour. Technol. 99: 3817-3828.

49. Mun WK, Rahman NA, Abd-Aziz S, Sabaratnam V, Hassan MA. 2008. Enzymatic hydrolysis of palm oil mill effluent solid using mixed cellulases from locally isolated fungi. Res. J. Microbiol. 3: 474-481.

50. Qiao JJ, Zhang YF, Sun LF, Liu WW, Zhu HJ, Zhang Z. 2011. Production of spent mushroom substrate hydrolysates useful for cultivation of Lactococcus lactis by dilute sulfuric acid, cellulase and xylanase treatment. Bioresour. Technol. 102: 8046-8051.

51. Pandiyan K, Tiwari R, Singh S, Nain PKS, Rana S, Arora A, et al. 2014. Optimization of enzymatic saccharification of alkali pretreated Parthenium sp. using response surface methodology. Enzyme Res. 2014: 764898.

52. Ang SK, Adibah Y, Abd-aziz S, Madihah MS. 2015. Potential uses of xylanase-rich lignocellulolytic enzymes cocktail for oil palm trunk (OPT) degradation and lignocellulosic ethanol production. Energy Fuel. 29: 5103-5116.

53. Ferreira S, Duarte AP, Ribeiro MHL, Queiroz JA, Domingues FC. 2009. Response surface optimization of enzymatic hydrolysis of Cistus ladanifer and Cytisus striatus for bioethanol production. Biochem. Eng. J. 45: 192-200.

54. Gao Y, Xu J, Yuan Z, Zhang Y, Liu Y, Liang C. 2014. Optimization of fed-batch enzymatic hydrolysis from alkali-pretreated sugarcane bagasse for high-concentration sugar production. Bioresour Technol. 167: 41-45.

55. Fang HHP, Liu H (2002) Effect of $\mathrm{pH}$ on hydrogen production from glucose by a mixed culture. Bioresour. Technol. 82: 87-93.

56. Norfadilah N, Raheem A, Harun R, Ahmadun FR. 2016. Bio-hydrogen production from palm oil mill effluent (POME): a preliminary study. Int. J. Hydrog. Energy 41: 11960-11964.

57. Panagiotopoulos I, Bakker R, De Vrije T, Van Niel E, Koukios E, Claassen E. 2011. Exploring critical factors for fermentative hydrogen production from various type of lignocellulosic biomass. J. Jap. Inst. Energy 90: 363-368.

58. Garritano AD, de Sa LRV, Aguieiras ECG, Freire DMG, Ferreira-Leitao VS. 2017. Efficient biohydrogen production via dark fermentation from hydrolized palm oil mill effluent by non-commercial enzyme preparation. Int. J. Hydrog. Energy 4249: 2916629174

59. Chong ML, Rahim RA, Shirai Y, Hassan MA. 2009. Biohydrogen production by Clostridium butyricum EB6 from palm oil mill effluent. Int. J. Hydrog. Energy 34: 764-771.

60. Zahrim AY, Rachel FM, Menaka S, Su SY, Melvin F, Chan ES. 2009. Decolourisation of anaerobic palm oil mill effluent via activated sludge-granular activated carbon. World Appl. Sci. J. 5: 126-129.

61. Arooj MF, Han SK, Kim SH, Kim DH, Shin HS. 2008. Continuous biohydrogen production in a CSTR using starch as substrate. Int. J. Hydrog. Energy 33: 3289-3294.

62. Cheng J, Su H, Zhou J, Song W, Cen, K. 2010. Microwave-assisted alkali pretreatment of rice straw to promote enzymatic hydrolysis and hydrogen production in dark- and photo-fermentation. Int. J. Hydrog. Energy 36: 2093 -2101.

63. Ibrahim MF, Abd-Aziz S, Razak MNA, Phang LY, Hassan MA. 2012. Oil palm empty fruit bunch as alternative substrate for acetone -butanol -ethanol production by Clostridium butyricum EB6. Appl. Biochem. Biotechnol. 166: 1615-1625.

64. Raghavi S, Sindhu R., Binod P, Gnansounou E, Pandey A. 2016. Development of a novel sequential pretreatment strategy for the production of bioethanol from sugarcane trash. Bioresour. Technol. 199: 202-210.

65. Williams BC, McMullan JT, McCahey S. 2001. An initial assessment of spent mushroom compost as a potential energy feedstock. Bioresour. Technol. 79: 227-230.

66. Russel M, Basheer PAM, Rao JR. 2005. Potential use of spent mushroom compost ash as an activator for pulverized fuel ash. Constr. Build. Mater. 19: 698-702.

67. Hui Z, Jianhua L, Dai Jianqing CM, Yi C. 2007. The alternative uses of spent mushroom compost. Spore 4: 1-22.

68. Najafi B, Faizollahzadeh AS, Shamshirband S, Chau KW. 2019. Spent mushroom compost (SMC) as a source for biogas production in Iran. Eng. Appl. Comput. Fluid Mech. 13: 967-982. 